\title{
MEMOIRS
}

\section{CYRIL DOUGLAS RICH}

Cyril Douglas Rich was born at Croydon on 22 May igor and died on 12 August 1956 after a long and painful illness. Of modest and unassuming disposition, he was serious-minded by nature and combined high intellectual qualities and integrity of character with a dry sense of humour which endeared him to all who knew him well. Compelled to undergo a serious operation in April 1955, he faced this prospect and the ensuing struggle to regain his health with the greatest fortitude. He had been a Fellow for thirty years, and for all but one of these had served the Institute in a wide variety of posts, ranging from Tutor to Vice-President. Of him it can truly be said that he was a 'help and ornament' to his profession.

Rich was educated at Haileybury and Trinity College, Cambridge. At school he gave early evidence of his exceptional abilities by gaining Junior and Senior Scholarships, and subsequently an Entrance Scholarship to Trinity. There he continued to win distinction and took his degree in 1923, being a Wrangler with 'B star' in the Mathematical Tripos.

On leaving Cambridge he entered the service of the Provident Mutual Life Assurance Association and qualified as a Fellow of the Institute only three years later. His qualities were soon recognized by his appointment as Assistant Actuary in 1928 while he was still only 26. Later he was appointed Assistant Manager and Secretary (194I), Deputy Actuary (1949) and Actuary (1952), a post he held until his retirement through ill-health in 1956 . A former business colleague writes of him:

'Whatever type of work Rich was given to do-from the most routine and monotonous to the most technical or responsible-he performed it with skill, patience and meticulous care. He mastered every new job quickly, thoroughly and with apparent ease....'

He had, in fact, the somewhat rare combination of a very keen appreciation of matters of detail, a great capacity to deal with them, and at the same time a sure judgment of broader issues.

Rich's exceptional services to the Institute began in 1927. From then until the outbreak of war in 1939 he was closely associated with the examinations, first as Tutor, then as Assistant Examiner (1932-34) and finally as Examiner (1934-40), acting for the last three of these years as Secretary to the Board of Examiners. During this period he submitted two papers for discussion at the Institute, The measurement of the rate of population growth (F.I.A. 65,38 ) and $A$ general theory of mortality (F.I.A. 70, 3I4); both these papers were awarded prizes from the Messenger and Brown Prize Fund, and the second, in particular, will be remembered by many as a paper of great originality which won wide commendation. Earlier he had contributed a note on calculation methods as an Appendix to Coutts's paper On the distribution of life office profits (F.I.A. 57, I 59).

In 1938 Rich became Assistant Editor of the Fournal, and in 1942 Editor, a post he held with distinction until 1948 when the Institute honoured him by appointing him an Honorary Secretary. On completing his two years in this 
post, he undertook the Editorship of the Year Book in succession to Menzler, whose high standards he fully maintained, besides introducing many ideas of his own before he handed on to his successor in 1954 . He was further honoured in 1953 by appointment as a Vice-President of the Institute.

Besides all this continuous work for the profession, Rich gave valuable service as a member of the Council from 1946 to 1951 and from $195^{2}$ until his death. His contributions to Council and Committee work were always clearsighted and often original, and particular mention should be made of the leading part he played in the allocation of the many gifts received by the Institute and other matters associated with the return to Staple Inn, and of his keen interest in the work leading up to the Grant of Arms to the Institute. $\mathrm{He}$ was the original Chairman of the Committee considering the intricate heraldic problems involved and carried through most expertly the considerable amount of initial investigation required. Even during his illness he continued to make valuable comments on the proposals made by the Committee.

In 195 I he was nominated as one of the Institute representatives on the Council of the Permanent Committee for International Actuarial Congresses, becoming in 1954 Secretary for Great Britain, and National Correspondent for England; both these offices he held at the time of his death. He made many friends during this period among actuaries overseas, especially in Holland and Belgium.

The regard in which Rich was held by his professional colleagues was shown by his election to membership of the Gallio Club in 1937, and of the Actuaries Club in 1948. The Gallio Club, choosing him as their Chairman for the 1954/5 Session, found his genial and courteous manner in the Chair, with his light and humorous touches, much to their liking.

No account of Douglas Rich would be complete without reference to his wife and family, whom he held so dear. Their courage and devotion in the last months of his life were beyond praise, and gave him strength to bear his long ordeal. $\mathrm{He}$ found great happiness in his home life. There he enjoyed relaxation from the work which absorbed so much of his time. He was keenly interested in everything connected with his family's varied activities and was himself a useful pianist. Music brought him great pleasure and he often wished he had had more time to devote to it.

All his many services to the Institute he loved well bore the mark of ability and distinction. He inspired the affectionate regard of everyone who came in touch with him, and their admiration in his brave fight against his illness. He will be sadly missed.

B. R. 